Martin D. Henry (ITQ, vol. 67/2, 2002, 152)

\title{
The Kabbalah, Paul Celan, and a View of Redemption
}

The Kabbalah (literally, 'received' or 'tradition') is a mystical, esoteric form of Judaism which flourished especially in Spain and southern France in the twelfth and thirteenth centuries. Like so many forms of Judaism, it has also been influential on Christianity, and was studied by, among others, the Renaissance philosopher Pico della Mirandola (1463-1494) and the German humanist Johannes Reuchlin (1455-1522). The Kabbalah contains speculations about the nature of God and the relationship between God and the universe. Both its view of creation (resulting not from the overflowing of God's goodness, but from an act of divine self-limitation that permits the world to emerge) and of redemption ('the Kabbalah . . . made the salvation of God by man, the tikkun, as vital a matter as its contrary' ${ }^{1}$ ), are at first sight startling doctrines.

The unconventional notion of redemption as applying to God, rather than man, can also be found in Paul Celan's poem, 'Tenebrae', to which I alluded in 'Reflections on Grace (3)'. ${ }^{2}$ To what extent, if at all, however, Celan may have been influenced by the Kabbalah, is unknown to me, but he 'was very familiar with Jewish tradition and was an ardent reader of Gershom Scholem's studies on Jewish mysticism'. ${ }^{3}$ Michael Hamburger observes that 'Celan is known to have been well versed in both [Jewish and Christian mysticism]' ${ }^{4}$ Celan's poem, hovering between a tormented mockery of the traditional religious understanding of redemption, and a harrowing awareness of a newly discovered religious no man's land, is, like all his poetry, written in reaction to the

1 Martin Seymour-Smith, The 100 Most Influential Books Ever Written: The History of Thought From Ancient Times to Today (New York: Citadel Press), 2001, 12. The tikkun itself, Gershom Scholem defined as 'the restitution of cosmic harmony through the earthly medium of a mystically elevated Judaism' (quoted in Sander L. Gilman and Jack Zipes [eds.], Yale Companion to Jewish Writing and Thought in German Culture, 10961996 [New Haven and London: Yale University Press, 1997], 408). For an overview of the Kabbalah, see G. Scholem, Kabbalah (New York: Meridian/Penguin, 1978).

ITQ, 67 (2002), 64.

S.L. Gilman and J. Zipes (eds.), op. cit., 720.

See Paul Celan, Selected Poems, tr. and intro. Michael Hamburger (Harmondsworth: Penguin Books, 1990), 29. 
murderous enactment by the Third Reich of the kind of volatile political messianism that was, ironically, so powerful in certain Jewish circles a few centuries earlier, as 'Sabbatianism', 5 a movement itself influenced by kabbalistic ideas.

That such initially perhaps somewhat shocking ideas on redemption, as one finds in kabbalistic writings or in Celan's 'Tenebrae', were even thinkable is an indication of not just how intractable - and yet how resilient - the challenge of evil to belief in God actually is, but they also show how any account, no matter how disturbing, of the reality of evil and suffering, seems to be preferable to no account at all, and even more so, how even the suggestion that there might be a 'point' to evil and suffering, seems to some to be not too high a price to pay for saving the idea of 'God'.

5 See G. Scholem, Die jüdische Mystik in ihren Hauptströmungen (Frankfurt a/M: Suhrkamp, 1980), ch. 8, on the Messianism of the tragic figure, Sabbatai Zevi. 